\title{
Islam and Economic Development
}

\section{By Muhammad Umer Chapra, The International Institute of Islamic Thought and Islamic Research Institute, Islamabad, Pakistan, 1993, 166 pp.}

Islam and Economic Development is another intellectual contribution by M. Umer Chapra, a well-known Muslim social scientist and author of Toward a Just Monetary System and Islam and the Economic Challenge. He has been devoting time, energy, and experience to the cause of Islamization of knowledge, and this work, which shares much in theme, tone, and territory with his earlier works, reflects his deep commitment and dedication to a painstaking task. This thought-provoking book, which offers a global and integrative perspective of the phenomenon of development within the framework of an Islamic worldview, is divided into six chapters, preceded by the author's preface and a foreword by Zafar Ishaq Ansari, and followed by notes and references, a bibliography, and an index.

Chapter 1, "The Kind of Development," initiates the discussion of the book's general theme by presenting the issue of development in terms of goals and the strategies employed to realize those goals. The two basic goals-efficiency and equity-are defined within the Islamic concept of just development, which is derived from the concepts of tawhid (the oneness and unity of God), khiläfah (the vicegerency of human beings), and 'adālah (justice).

The terms "efficiency" and "equity," as defined on page 8, need further explanation, especially when the author has discussed the important analytical issue of the optimality and the maximization of the two variables. Moreover, the concept of khiläfah (state) and the two basic goals that it seeks to achieve, 'adälah (justice) and faläh (general wellbeing), could have been better linked to the three basic pillars of Islam: tawhid, risälah (prophethood), and äkhirah (the hereafter).

Chapter 2, "Can Secularism Foster Just Development?," features development strategies of the two prominent secular systems: the free market system and the socialist system. Chapra points out that the reallocation of resources cannot be realized within the value-neutral framework of secular systems. He notes that the free market system, which is based on the concept of self-interest, cannot motivate people to act in the interest of society. He shows the futility of the swirling pattern 
of government policies designed to overcome market failures. He also presents a diagnosis of the socialist system, showing that its strategy of development, which is free from moral imperatives and lacking in economic incentives, is not consistent with the concept of just development.

Chapter 3, "The Inconsistency of Development Economics," provides a critical review of the theory and practice of economic development as extended and advanced during the past three decades. Chapra shows the flaws and inconsistencies present in development strategies, which are built on a mix of the neoclassical economic thought and the development planning of socialist thought. He argues that implementing inappropriate strategies has generated severe internal and external imbalances in the economies of many developing countries without accelerating the process of development.

In chapter 4, "The Islamic Strategy," Chapra builds a basic framework for the formulation of a development strategy based on Islamic principles. He suggests that both the social and economic aspects of human life must be taken into consideration while designing a strategy that would ensure development with justice and stability. Thus, an Islamic economic order needs to be treated as a subsystem of Islamic social order. In such a system, it would be assumed that moral values would play a dominant role in the optimization of efficiency and equity in the use of resources. Chapra identifies four major elements for the development of such a strategy: moral filter, motivation, socioeconomic restructuring, and the state. The moral force serves as a mechanism to filter off excessive and unlimited consumer demands and as a curb on the wasteful use of limited resources. He argues that faith in the accountability and the system of punishments and rewards in the hereafter motivate people to do righteous deeds. The transformation of self-interest into social interest, under the impact of an inner moral force, reinforces the price mechanism and improves market efficiency.

Chapra also focuses on the need to restructure socioeconomic institutions so that they will conform to Islamic norms. The role of the government in the process of restructuring is stressed. Many other factors that supplement and complement in actualizing the Islamic vision of development are discussed in detail. But somehow, several important factors-the internal and external migration of labor, the quest for resource redistribution, and the development of technology through investment in research and development, seem to have been overlooked. Moreover, Chapra has avoided the use of constructs that show the causeand-effect relationship between identifiable and quantifiable variables. This oversight renders his presentation amenable to serious criticism from economists who are mathematically oriented. 
In chapter 5, "Why the Failure?," Chapra explains that, among many other causes, the political factor is the major element that has been responsible for the failure of the Muslim countries to implement the Islamic strategy in their quest for development. He emphasizes the need to establish the khiläfah, which would be committed to the well-being of all human beings and ensure the equitable distribution of income and wealth.

Chapter 6, the conclusion of the book, delivers an inspirational message to the Muslim leaders and elite, who have grown complacent vis-àvis the free market system, to try the Islamic alternative. Chapra also provides food for thought for secular oriented economists by showing the relevance and applicability of the Islamic strategy when it comes to providing the best alternative for dealing with all of the various short-term and long-term problems. He makes a telling point by hypothesizing that material development with justice and stability is not possible without moral development. At a time when socialism has lost its appeal and the world seems to be attracted to free market system despite its deficiencies, shifting the locus of intellectual influence from the free market system to an Islamic system is not an easy job. There are many studies on the issue of development, but this is the first I know of that has organized the subject matter in such a simple, clear, and persuasive manner. The author is to be commended. This book is a valuable primer that can be used as a guide, rather than as a text, in the area of economic development as well as in the field of the comparative study of social systems.

Shujaat A. Khan

Asst. Professor Dept. of Economics St. John's University New York 